\title{
Islamic Law, Slavery, and Feelings
}

\section{A Fourth/Tenth-Century Andalusi Notarial Model on the Manumission of an Unruly and Bad-Tempered Female Slave}

Cristina de la Puente | ORCID: 0000-0002-2407-0076

Consejo Superior de Investigaciones Científicas, Madrid, Spain

c.delapuente@csic.es

\begin{abstract}
This article studies a fourth/tenth-century notarial model to limit and place conditions on (istir $\left.{ }^{\prime} \bar{a}\right)$ the manumission of an unruly and bad-tempered female slave. The text is part of al-Wathä'iq wa-l-sijillät, a notarial manual compiled by Cordoban scholar Ibn al-Ațtāar (d. 399/10o9), the earliest edited Andalusi work of this genre. Although it is part of a chapter on slavery and, more specifically, of a section dedicated to the manumission of slaves, it is not a generic notarial text dealing with the manumission of female slaves. The document is not a manumission form, but one that complements and limits a manumission; in fact, its aim is to impede or overturn the process. The article studies this notarial model in three different contexts: (1) Andalusi kutub al-wathä’iq, (2) Mālikī legal literature on slavery and (3) notarial model reservation testimonies. Even if, at first glance, it appears to be an unusual legal document, when analysing other Mālikī sources we observe that the text is part of a well-documented tradition with widely accepted legal justification. This model is nevertheless exceptional from a procedural point of view because its legal arguments are based on feelings and refer specifically to the slave's personality, temperament and behaviour as the factors that motivated the legal act.
\end{abstract}

\section{Keywords}

slavery - concubinage - notarial manuals - kutub al-wathāiq - manumission reservation testimonies - istir 'a $\bar{a}^{\prime}$ - Ibn al-'Ațtār - al-Andalus - Mālikī law 
Arabic legal literature rarely refers to human feelings. ${ }^{1}$ Sometimes, one can sense that a jurist's decision is based on humanitarian reasons; that is to say, by analysing the wording of certain doctrines, one can perceive the intention to protect the weak. However, it is unusual to find textual references to the characteristics of the personality of a human being or to decisions based on personal or emotional reasons. Muslim jurisprudence is not an exception in this regard, since one of the core principles of any legal system is the quest for equity and justice, which entails an absence of exceptions. Any irregularity that deviates from the norm and can be perceived as arbitrary must be carefully explained and justified. We can therefore assert that the study of legal texts that clearly reveal the intentions and feelings of the contracting parties is of scholarly interest. Moreover, when they belong to a theoretical treatise, such texts can be considered unique. Furthermore, if the intentions and emotions revealed therein are not exactly noble, what we have is an extraordinary text.

As well as a lack of references to emotions and feelings within primary sources, cases where these gain prominence are few and scattered, and have not drawn the attention of secondary literature. Lebanese jurist Choukri Cardahi was ahead of his time when he reflected on the legislator's role towards human feelings: "Le législateur [dans ces conditions], pour faire une œuvre salubre, devait s'arrêter à ces phénomènes émotifs, et tenir compte de leur nature ou de leur caractère dans les règles qu'il a mission d'édicter." ${ }^{2}$ Cardahi's awareness of the way in which emotions affected individuals and, consequently, their importance in legal regulations, did not influence historiography on Islamic law, and authors have rarely paid attention to sentimental and emotional issues.

Currently, motivational factors linked to human emotions are largely accepted among scholars as triggers of either minor or major actions that are frequently historically crucial in the same way as political, economic, or religious causes. These feelings drive desires, and desires induce actions.

This paper analyses a rare legal case with a high emotional content where feelings and human intentions are evident. The document is a notarial model

1 The present work has been carried out through the Research Project "Arabic Philology: text analysis for the study of the Western Arabic and Islamic World" (CSIC 201810Eo19), and the Research Project "Gender, family and slavery. Slavery and legal status in the structuring of Muslim families (8th-12th centuries)" (MICINN PID2019-110663RB-10o).

2 "Nos sentiments et nos passions devant la justice et la loi," Annales de la faculté de droit Saint-Joseph de Beyrouth 2 (1951), in Farouk Mechri, Le sentiment d'affection et le Droit de Famille (Tunis: Editions Latrach, 2015), 5 . 
that places a reservation testimony (istir $\left.\bar{a}^{\top}\right)$ on the manumission of a female slave supposedly being freed due to her being unruly and bad-tempered. ${ }^{3}$ This extraordinary legal document had surprisingly not been studied. It is included in the section on slave manumission in al-Wathä̉iq wa-l-sijilla $t^{4}$ by Cordoban jurist Ibn al-Atțār (d. 399/10o9). ${ }^{5}$ This notarial manual was written in the last years of the Umayyad caliphate of al-Andalus during the reign of Hishām II (r. 366-99/976-10o9, 400-3/1010-13), when his chamberlain al-Manșūr (d. 392/1002) de facto ruled over the entire territory. Al-Andalus enjoyed at that time political and social stability, which permitted abundant literary creation. The works composed during this period, not only in law, would serve as models for texts written under later dynasties, in more turbulent periods.

The present documental analysis must first consider that, in the Andalusi context, al-Wathä̉iq wa-l-sijillät is part of a legal genre that aims to collect notarial forms instead of records or scripts that result from real cases. An important part of the archival documentation of the pre-modern Islamic world has not been preserved; this is the case in al-Andalus and the Maghrib, where notarial documents had to be handed from one expert to another without any official registration to guarantee their conservation. In al-Andalus, due to the Christian conquest, only a small number of notarial documents from the ninth/fifteenth century have been preserved. ${ }^{6}$ With the loss of al-Andalus,

3 Istir ' $\bar{a}$ ', reservation is a juridical principle according to which a condition is imposed in a legal act.

4 Ibn al-'Ațțār, al-Wathā’iq wa-l-sijillāt, ed. P. Chalmeta and F. Corriente (Madrid: Instituto Hispano-Árabe de Cultura-Academia Matritense del Notariado, 1983). On the content of this work, see Pedro Chalmeta, "Un formulaire notarial hispano-árabe du IV/X s.: Glanes économiques," Revista del Instituto Egipcio de Estudios Islámicos 23 (1985-86), 181-202. The translation and study of this manual is also available in Spanish: Ibn al-'Aț̣ār, Formulario notarial y judicial Andalusí, ed. Pedro Chalmeta and Marina Marugán (Madrid: Fundación Matritense del Notariado, 200o); see review by Cristina de la Puente in Journal of the Economic and Social History of the Orient 45 (4) (2002), 524-26.

5 Ibn al-'Aț̣ār, al-Wathā’iq wa-l-sijillāt, 281-82 (section on manumissions, pp. 238-89). In the Spanish translation, Ibn al-'Ațtāa, Formulario notarial andalusí, chap. 17, 478-79 (n. 108).

6 On the fifteenth-century Andalusi documents see Amalia Zomeño, "Notaries and their formulas: The legacies from the University of Granada," in From al-Andalus to Khurasan:Documents from the medieval Muslim world, ed. Petra Sijpesteijn, Lennart Sundelin, Sofia Torallas Tovar and Amalia Zomeño (Leiden: Brill, 2007), 58-77; and Amalia Zomeño, "From private collections to archives: How Christians kept legal Arabic documents in Granada," al-Qanțara 32 (2) (2011), 461-79; María Dolores Rodríguez Gómez, "Describing the ruin: Writings of Arabic notaries in the last period of al-Andalus," Studia Orientalia 112 (2012), 71-101. About women in these documents, see Maya Shatzmiller, Her day in court: Women's property rights in fifteenthcentury Granada (Cambridge, Mass.: Harvard University Press, 2007). 
these documents became unnecessary and, as a result, their circulation was interrupted. Some, however, were kept in mosques, family archives, and the like, and, centuries later, we can fortunately have access to them.

Notwithstanding the disappearance of legal documents from previous centuries, which would have been of great help in the writing of the history of this part of the world, there are ample and rich sources of legal literature of doctrinal and theoretical character, which allows us to obtain a good idea of the content of missing documents. Furthermore, al-Andalus saw a flourishing of the notarial genre (shurūt), and Andalusi experts drafted summaries of notarial models (wathäiq). Some of the surviving works, such as the one analysed here, have been edited and studied by scholars. ${ }^{7}$ As mentioned above, these collections of notarial models, which have a theoretical nature rather than being real cases, were intended to be used by jurists to draft contracts and agreements in real life. They were conceived so that notaries could easily substitute the sections of the contract that refer to the parties, and add the specific details of the legal act at hand. These details would have provided excellent information that is only partially completed by the examples that jurists sometimes offer. We must remember that both the models and the examples tend to reflect the most frequently found cases of the period. However, the document studied in this article poses some questions on this last point.

Notarial manuals were structured according to the most usual order of the chapters of Mālikī books on applied law ( furū' al-figh). Each chapter contained several models for what was considered the most frequent legal situations. With each model, authors included a section on its jurisprudence ( $f$ igh $)$ to clarify doubts on the document's pertinence and to prevent possible conflicts. Besides, authors could make comments on the legal foundations the act was based on. Among the legal sources, they sometimes mention local customs, which allows us to observe regional differences, making these texts interesting for the social historical analysis of al-Andalus.

Legal acts related to slaves are important within this genre, as well as in the whole of pre-modern legal literature. Unsurprisingly, there is a specific section on manumission of slaves, since it is one of the legal acts for which written

7 In addition to Ibn al-Ațtāar's work, see Ibn Mughīth (d. 459/1067), al-Muqni'fí ilm al-shurūt, ed. Francisco Javier Aguirre Sádaba (Madrid: Consejo Superior de Investigaciones Científicas, 1994); Ibn al-Ḥājj al-Gharnāṭī (d. 579/1183), al-Wathā̉iq al-mukhtaṣara, ed. Mușțafā Nājī (Rabat: n.p., 1987); al-Jazīīī (d. 585/1189), al-Maqșad al-maḥmūd fì talkhịs al-'uqūd, ed. A. Ferreras (Madrid: Consejo Superior de Investigaciones Científicas, 1998); and Ibn Salmūn (d. 767/1365-6), al-Iqd al-munazzam lil-hukkām fì-mā yajrī bayna aydīhim min al-wathāì, edited in the margins of Ibn Farḥūn, Tabșirat al-ḥukkām, 2 vols. (Beirut: Dār al-Kutub al-'Ilmiyya, n.d.). 
testimony is essential, for two main reasons - to avoid fraud and misunderstandings, and for both parties to be able to prove their new status. In the case of the freed slave, the document would serve as proof of the acquisition of the rights of a free man or woman; for the slave owner, it would ensure the right to heritage and clientele. Manumission acts were used as safeguards in their new lives, making them particularly vital in cases where freed slaves wanted to move or leave the place where their previous legal status was publicly known. ${ }^{8}$

The case under study is part of a section on manumission; however, it is not an emancipation model. It is a text that establishes a condition for a manumission and, therefore, a text that must accompany another legal act, the manumission itself, that had to have its own notarial record. That means that this text complements another unidentified text, which could be any of the liberation documents included in the same chapter. This is probably the reason why this text was not included in the section on reservations or conditions. However, it does not explain why a reservation is done on an act that, at least theoretically, cannot be legally conditioned without it being overturned. It must be taken into consideration that a slave's manumission is not just a legal act, but also a religious one. For Muslims, emancipation is a good action recommended by God in the Qur'ān. As stated by Joseph Schacht, manumissions, just like conversions, are considered "desirable transactions." ${ }^{\text {"Therefore, }}$ jurisprudence treats liberation as sacred and ensures the absence of conditions. It even foresees abolishing conditions that were previously set, to avoid any obstacle or delay to the manumission. ${ }^{10}$

The chapter on liberation contains 21 notarial models regarding different types of manumission - contractual (kitāba), post-mortem (tadbīr), definitive

8 We must consider, on the other hand, that slaves actively or passively participate in many other legal acts, not only in those related to manumissions. For example, female slaves have special relevance in the chapters on marriage: Cristina de la Puente, "Slaves in al-Andalus through Mālikī wathāiq works (4th-6th centuries H./1oth-12th centuries $\mathrm{CE}$ ): Marriage and slavery as factors of social categorisation," Annales Islamologiques 42 (2008), 187-212.

9 Joseph Schacht, An introduction to Islamic law (Oxford: Oxford University Press, 1964), 118.

10 Numerous examples can be given of the determination of the fuqah $\vec{a}^{\prime}$ to ensure that the liberation is fulfilled, from prohibiting the rectification of a post-mortem manumission to the obstacles imposed on the owner who wants to prevent his contractual slave (mukātab) from completing the payments and acquiring freedom. See, e.g., Mālik b. Anas. Kitāb al-Muwatța' and Al-Ṣuyūțī, Is āâf al-Muwațtá bi-rijāl al-Muwatța', ed. Farūq Sa'd (Beirut: n.p., 1401/1981), K. al-mukātab: 689-9o; Ibn Abī Zayd al-Qayrawānī, Risāla/La Risāla ou Epître sur les éléments du dogme et de la loi de l'islam selon le rite mâlikite. Texte arabe et traduction française avec un avant-propos, des notes et trois index par León Bercher (Alger: n.p., 1968): 224/5; Ibn Rushd al-Hafīd (Averroes), Bidāyat al-mujtahid wa-nihāyat al-muqtasid (Beirut: Dār al-Márifa, 1409/1988), 2:374. 
(batil), of a part of a slave shared by two partners ('abdun mushtarak ${ }^{u n}$ bayna sharikayn), etc. - from which this model is the only text in which a condition is established. ${ }^{11}$ Moreover, this reservation was not perceived as eccentric or a legal anomaly by other Andalusi notaries in the following centuries, as it was included in later manuals together with forms for slave liberation.

\section{$2 \quad$ A Unique Legal Model in Mālikī Jurisprudence}

On this occasion, the short extension of the notarial model allows us to include its full translation: ${ }^{12}$

Reservation deed in a manumission:

So and so, son of so and so, has requested testimony from the witnesses of the present letter that established a reservation: when he grants to a Galician or Frank slave, either blonde or black ${ }^{13}$ - so and so, whose signs are such, the definitive manumission - or the manumission at term, or the type of manumission that he subscribes - he will do so because of the detachment that she shows him, and to keep her happy - or with the purpose of procuring a correct treatment and keeping her services - without being obliged to this release or feeling linked [to its fulfilment]. He retracts it, since he does not arrange it to obtain divine reward or to do a good act. He frees her for the aforementioned reasons: her indolence, irritability, having gone beyond the limits of correction, and her negligence when she comes to fulfilling her obligations to him, as her owner. So that, for this liberation, she surrenders and changes her behaviour in exchange for the desired achievement of the aforementioned freedom, through her correct service and conduct.

The witnesses attest to the testimony required by Doe, son of Doe.

And complete the writing

\footnotetext{
11 Ibn al-'Ațtāar, al-Wathā̉iq wa-l-sijillāt, chap. 17, form nos. 91-111.

12 Ibn al-'Aț̣ār, al-Wathāii wa-l-sijillät, 238-89; for its translation into Spanish, Ibn al-'Aț̣ār, Formulario notarial, 437-84 (nos. 91-111).

13 Ibn al-Ațtāar in notarial models usually presents the most frequent types of slaves in tenth-century al-Andalus. In this period, there were many enslaved captured Christians from the north of the Peninsula. See Cristina de la Puente, "The ethnic origins of female slaves in al-Andalus," in Concubines and courtesans: Women and slavery in Islamic history, ed. Matthew Gordon and Kathryn A. Hain (New York: Oxford University Press, 2017), 132, $135^{-3} 6$.
} 
Jurisprudence

The aforementioned reservation cancels the manumission, even if the witnesses have not seen the bad behaviour mentioned by the owner. It is the same as the reservation of a manumission recorded in the Mustakhraja about a man whose slave escaped into enemy territory. Muslims attacked that region, and his owner saw him in the enemy army. He said in front of Muslim witnesses: "I want to invite him to come back, and come out to meet me in exchange for manumitting him; but without this condition being binding, since my only purpose is to get him out of there." He then told the slave he would free him, and the slave returned. Mālik, asked about this, said: "The owner is not bound by the manumission and the slave remains his servant."

This question is analogous to basing the reservation on a pious foundation (hubs) ${ }^{14}$ since no hadīth regarding the hubs has been transmitted, and nobody disputes that the reservation in the case of the hubs is valid. In these circumstances, experts used to dictate fatāwa . If it is valid in the case of hubs with the declaration of the person instituting the legacy, without knowing the reason for making a reservation, it is also valid for manumission and similar deeds. So, it would be valid, even if there was no tradition on manumission, and all the more so, if there was. If someone says that the reason for the reservation in the case of the slave who flees to join the enemy, is evident and known, we are again faced with a case of those compiled by the experts about the legality of the reservation in the hubs without the reason being known. It would be absurd to condemn the owner to carry out a manumission, who, before formulating it, had already declared that he did not intend to or commit himself to it.

All the peculiarities mentioned of this notarial model immediately lead us to ask two questions: Why is this document drafted to overturn another one? And, is this possible according to Mālikī jurisprudence? The answers to these questions can be found in the complex legal concept istir' $\bar{a}$.

14 In al-Andalus, pious foundations that in the Orient are referred to as waqf (pl. awqā $f$ ) are called ḥubs (pl. ahbās). Ana María Carballeira Debasa, Legados píos y fundaciones familiares en al-Andalus (siglos IV/X-VI-XII) (Madrid: Consejo Superior de Investigaciones Científicas, 2002). 
Reservation documents are a complex issue not only because they include texts in which conditions are imposed on a legal act but also because they are part of a varied casuistry of public and private acts. Among them we find, for example, numerous certifications on someone's personality, identity or probity, questions needed to identify the rights and obligations that correspond to a person. Under the common denomination of reservation, very different types of legal acts are included - on the one hand, there are models designed so that the correct legal procedure is followed and confusion does not arise later on; on the other, there are acts related to a right that cannot be claimed after some time, ${ }^{15}$ and, finally, there are models designed to put a condition on an act that has not yet been carried out. In the latter, we must remember that not all legal acts are subject to a term or a condition. This is allowed in cases of repudiation, manumission, and inheritance. ${ }^{16}$

In David Santillana's classic work on Mālikī law, we find the legal concept of istir ' $\bar{a}$ ' in the section dedicated to "suspension of the prescription." Santillana indicates the following: "... when the prescriber is a powerful and feared man, against whom one cannot act through ordinary judicial channels. The ancient doctrine advises the plaintiff in these cases to make a secret protest through notaries, making them take note of the cause that prevents him from acting; but this secret act (istir $\left.{ }^{(} \tilde{a}^{\prime}\right)$ is considered superfluous by contemporary jurists, according to who it is enough, in order to preserve the rights of the injured party, that the facts be known and that the prescriber is a feared man." ${ }^{17}$ In the final glossary, he defines the term as "secret protest through notaries, making note of the cause that prevents him from acting."18 Santillana refers to reservations that imply a condition and points to two relevant issues: (1) that it was almost always done for secret acts, and (2) that these acts were undertaken due to fear. Reservations may even be conditioned by coercion (ikrāh) or disgust (inkār), which would explain the secrecy of many of these acts. It could also explain why Ibn al-'Ațtāir considered that it was not necessary that the witnesses know the reason for the reservation. ${ }^{19}$

15 Ibn al-Atțār, Formulario notarial, $5^{27}$.

16 Schacht, Introduction, 119.

17 David Santillana, Istituzioni di diritto musulmano malichita con riguardo anche al sistema sciafita (Rome: Istituto per l'Oriente, 1926), 1:348 (e).

18 Santillana, Istituzioni, 2:722.

19 Ibn al-Ațtāar, Formulario notarial, 528-29. 
Another relevant issue that Santillana points out is that reservations were being used less and less frequently. Ibn al-Ațțār was long considered the primary source for this genre of records, but later jurists pay less attention to his writings; some replicate the models of the Cordoban jurist, although others do not include the subject or barely address it. ${ }^{20}$

Ibn al-Atțār includes a specific section dedicated to reservations, where he collects nearly forty models related to declarations of enmity, incapacity, prodigality, disqualification, emancipation, abuse or compromise, that is, certifications that are complementary to other legal acts which are, in many cases, necessary for the act to be fully valid. ${ }^{21}$ Additionally, in the section dedicated to pious foundations, he includes three models that are conditions imposed on pious foundations $(a h b \bar{a} s)$ in addition to the model inserted in the chapter on manumissions, which is the object of the present study. ${ }^{22}$ These models contain a voluntary and unilateral statement made in front of witnesses. In cases where there is another party involved - in this case, the slave - this party is mentioned but does not participate actively in the drafting of the document. Regarding the secrecy of the document, although not expressly mentioned, we can sense that in some cases the deed was drawn up to make it public immediately or to be used in a public act, such as a trial. In other cases, the intention was to keep it secret until it was used. Possibly, Santillana refers to these documents as secret because one or more people might have been involved in the legal act without knowing its content. Finally, we must take into consideration that reservations always originate from a specific need related to another legal act that requires said testimony. ${ }^{23}$

\section{Ibn al-'Ațtāar's Legal Arguments on This Reservation}

This notarial act presents the main characteristics of reservations that have been explained in the section above: (1) reservations are previously established in a private document; (2) a reservation is a voluntary act; (3) following Islamic law, reservation deeds can only be established in the three types

20 al-Jazīīi, al-Maqșad, 296-97 (aḩbās), 392-406 (certifications) and 432 (manumissions). Ibn Mughìth, Al-Muqni' includes this manumission act and an istir 'á' fi l-walä', 356-57.

21 Ibn al-Ațtāar, al-Wathā’iq wa-l-sijillāt, 319-404.

22 For the three models, see Ibn al-'Ațtāir, al-Wathā’iq wa-l-sijillāt, 232-35.

23 David S. Powers, Law, society and culture in the Maghrib, 1300-1500 (Cambridge: Cambridge University Press, 2002), 31. 
of legal acts mentioned above: repudiation, manumission, and inheritance; and (4) reservation is motivated by fear - in this case, fear of the female slave's temper. Ibn al-Ațtāar mentions some of these points in the course of his analysis.

AQ1. The model specifies that, whether manumission is definitive ('itq batil), whether it is to be carried out in only one immediate act or at a previously defined future date ('itq mu'ajjal), said liberation will not take place, because the owner frees the female slave [supposedly] to appease her bad temper and not as a generous act to "obtain a divine reward or to do a good deed." To clarify any doubts about that intention, Ibn al-'Ațtār decrees the nullity in the first sentence of the jurisprudence section: "Said reservation annuls the manumission, although the witnesses are unaware of the bad behaviour mentioned by the owner." An initial hypothesis would be that the notary is complicit in deceiving the female slave, considering it to be a lesser evil which will lead to a happier living arrangement. Ibn al-'Ațtār's jurisprudential argumentation seems to support this, and he uses the comparison of the validity of the reservation in this case with other similar ones. First, the Cordoban jurist compares this case with a false promised manumission in the heat of battle. In this example, Mālik b. Anas, the founder of the legal school, decrees the manumission's nullity because it was done with a false promise from the beginning. Ibn al-Ațtār asserts that this question (mas'ala) is included in the Mustakhraja of al-'Utbī, the most relevant Andalusi doctrinal work of the third/ninth century. ${ }^{24}$ Although the notary refers to this text only briefly, particular attention should be paid to this work in order to understand the legal interpretation that jurists develop afterwards, as it opens a way for nullity:

Mālik said in the case of his slave who escaped to enemy territory: "Come back with me, so and so, and you will be free." He came back and said, "I just wanted to get you [out of there]" and claimed that he had given public testimony (ashhada) and that he only wanted to say that to convince and capture him. In that case, he was not obliged to release

24 al-'Utbī's (d. 255/869) work is preserved thanks to the commentary by Ibn Rushd alJadd (d. 520/1126), al-Bayān wa-l-taḥșil wa-l-sharh wa-l-tawjịh wa-l-talīl fì masāil alMustakhraja (Beirut: Dār al-Gharb al-Islāmī, 1984-91). On al-'Utbī's Mustakhraja, see Ana Fernández Félix, Cuestiones legales del islam temprano: La 'Utbiyya y el proceso de formación de la sociedad islámica andalusí (Madrid: Consejo Superior de Investigaciones Científicas, 2003). 
him; had he not testified a priori, the servant would have had the right to be free. ${ }^{25}$

The key idea that is inferred from this text is that it is not a reversal of opinion, but something that had already been publicly expressed in front of witnesses. As stated clearly at the beginning of the model, this act is a reservation made on a manumission that has not yet taken place but that will supposedly take place in the future. This is significant because legal acts cannot be overturned ex post by one of the parties, and it is considered that reservations or conditions must always be prior to the legal act's ratification.

Ibn Rushd's commentary on this passage addresses the same idea. Although this complex commentary is dated two centuries after Ibn al-Ațtār's notarial manual, it is relevant because it contains the different forms of "reservation" and existing discrepancies on this legal principle within the Mālikì school. Averroes's grandfather states that: ${ }^{26}$

This is a controversial matter. Mālik b. Anas in his section on "who begins to drink wine" of the "chapter of loan and insolvency" (Kitāb al-midyān wa-l-taflis) has said about the man who has a right over another man but the [second] man does not recognize this right: and then, said person invites the latter to reconciliation and is reconciled with him; and his witnesses (shuhüd) are absent (ghayb); and he has had witnesses testify in secret ( $f^{i} l$-sirr). [The former] only wanted to be reconciled with him because the latter did not recognize the right and [the former himself] was afraid of losing the right. ${ }^{27} \mathrm{He}$ [the former] keeps the right if his witnesses and evidence are present: reconciliation (sulh) is an obligation / a need for him, and does not benefit him.

Aṣbagh ${ }^{28}$ mentions in his legal proceedings ( finawazzili-hi), in the chapter on "complaint and reconciliation" (kitäb al-da'wa wa-l-șulh), that [the former] benefits from the testimony (of the witnesses that are absent and

25 The Mustakhraja text to which Ibn al-Ațtāar refers is part of Ibn Rushd al-Jadd, al-Bayān wa-l-tahṣull, 14:395-96. Ibn Rushd develops his own interpretation in response to al-'Utbīs question.

26 I thank my colleague and friend Nassira Kouici for her help in interpreting this text.

27 Lit., "That his right left him."

28 Abū 'Abdallāh Aṣbagh b. al-Faraj al-Umawī (d. 225/839), traditional Egyptian jurist, one of the main transmitters of the Mālikī doctrine. Jonathan Brockopp, "Aṣbagh b. al-Faraj," in Encyclopaedia of Islam, THREE, ed. Kate Fleet, Gudrun Krämer, Denis Matringe, John Nawas, and Everett Rowson. Consulted online on 16 July 2020. First published online: 2009 . 
far), and the persistence of this difference (between Mālik and Așbagh) is recorded in the "books of technicalities" (kutub al-iștilăhăt) and it lies in "the reservation" (al-istir' $\left.\bar{a}^{\prime}\right)$ and "the reservation within the reservation" (al-istir ' $\tilde{a}^{\prime} f \iota^{l}$-istir ${ }^{\prime} \tilde{a}^{3}$ ). Among the writers there are some who add that it is repeated, has expired, and does not make any sense, since the reservation $\left(\right.$ al-istir $\left.{ }^{\prime} \bar{a}\right)$ means that he testifies in secret before the reconciliation that he is reconciled with the other for that reason, and in this case, he does not commit himself to reconciliation (fa-huwa ghayr multazim lil-șulh). Whereas the reservation within the reservation (al-istir ' $\bar{a}^{\prime} f^{\prime} l$ l-istir $\left(\bar{a}^{\prime}\right)$ means that one testifies that one does not commit himself to reconciliation, and that when he reconciles and has witnesses testify about himself in the book on reconciliation, is deprived of istir ' $\bar{a}$ in secret; in that case, he does not commit himself, and does not deprive himself of its fulfilment (of reconciliation). A third opinion (manzila thălitha) cannot be imagined. And this secret reservation (istir 'a $\tilde{a}^{\prime} f($ l-sirr) is only useful for those who see it advantageous when it is left without compensation; whereas if he receives a compensation from the contracts, in such a case there is no discrepancy in that the reservation $\left(\right.$ al-istir $\left.{ }^{(} \bar{a}\right)$ is useless. ${ }^{29}$

Taking into consideration these legal subtleties, Ibn Rushd al-Jadd (the grandfather) insists that the imposed condition on a sole act is licit if it is made previously, and he states as a fact that the author of the reservation must specify the reason for executing the legal act. Discrepancies between Mālik and his disciple are procedural, as they do not agree on either the ways or the time of establishing a reservation on a legal act, i.e., the moment and whether it is done privately or publicly. Moreover, jurists related the procedure followed with the intention of the person who imposed the condition, given that the procedure itself becomes proof of the motives that caused the reservation to be established.

In addition to the question of when the reservation is made, Ibn Rushd pays attention to the absence of witnesses. The author mentions that the reservation was made in secret and wonders if this has an effect on the procedure. Léon Buskens, referring to a later period, states that "in an istir'ä' document the 'udül put into writing the testimony of other persons. In this case there is no guarantee of the moral integrity of the direct witnesses, only of those who put their testimony in writing." ${ }^{30}$ However, nothing in Ibn Rushd's text

29 Ibn Rushd al-Jadd, al-Bayān wa-l-tahṣill, 14:395-96.

30 León Buskens, "Writers and keepers: Notes on the culture of legal documents in Morocco," in The vellum contract documents in Morocco in the sixteenth to nineteenth centuries, ed. 
seems to indicate that the witnesses, despite being absent, do not speak in their own name.

Ibn al-'Atțār's second argument is also an analogy. He compares a reservation on a manumission to the case in which a condition is imposed on a religious foundation (hubs). ${ }^{31}$ The religious foundation, just like a slave's liberation, is a religious act aimed at doing a good deed that can be revoked as long as the condition to revoke it has been stated previously. In the same way as in liberations, overriding a foundation that has already been legally made is not permitted, unless a reservation act (istir $\left.{ }^{(} \vec{a}\right)$ or a precautionary act (taqiyya) was previously carried out. Another way of cancelling a religious foundation is to have previously established, in front of a notary, that the hubs would be sold later. ${ }^{32}$ If a notarial act was drawn up where the legatee stated that he did not intend to establish the hubs as a good deed to please God, this same argument can apply to a reservation on a manumission (wa-anna-hu räji ${ }^{\prime}$ un $f i-h i$ idha laysa ya'qidu-hu ibtighă'un al-ajr wa-là irādatu-hu wajh Allāh al-'azìm = He revokes this as it does not concern the obtention of the divide reward nor to make a good deed).

For Carballeira, the aim of drafting this type of act would be the desire to evade a threat to a property that one did not want to lose. For example, an expropriation could be avoided by pretending to institute a $h u b s .{ }^{33}$ We could also think about a less noble cause - that the legatee wished to publicly exhibit generosity but made the reservation to have the possibility to recover the bequeathed object later. In any case, reservations can only be put into effect when they have been established prior to declaring the setting up of the religious foundation, in the same way as in manumission cases.

The Cordoban jurist does not explicitly mention some aspects of the reservation, possibly because he considers them as widely known and inherent to it. First, the confidentiality of the acts, as both the reservation in the manumission and the reservation in the pious legacy are secret documents. In both cases, in the case of the female slave in the manumission and in that of the inhabitants of a city who believe they are the beneficiaries of a legacy, the parties are not aware that, in fact, that is not the case. In addition, all of them ignore the reason, as it was mentioned in a separate document that was kept

Toru Miura and Sato Kentaro (Tokyo: The Toyo Bunko, 2020), 101. Buskens (101-3) makes a synthesis of the reservation documents that are divided into two categories, according to his witnesses: istir' 'á ' 'adlī and istir'a' lafífí.

31 See reservation models in a hubs in al-Andalus, in Ibn al-'Ațtāar, al-Wathā’iq wa-l-sijillāt, 232-35; al-Jazīīi, Maqșad, 296-97.

32 See conditions on these in Carballeira Debasa, Legados píos, 334.

33 Carballeira Debasa, Legados pios, 334. 
secret from them. Therefore, these reservations affect third parties, although the lawyer does not seem to consider it harmful. In the case of manumission, the reservation affects a specific person, a slave; in the case of the hubs, it can affect either one or several persons.

The second feature of the notarial model that Ibn al-Ațạar does not comment on is the fact that the reservation is motivated by the bad character of the female slave. As we have seen, one of the main characteristics of the istir ' $\bar{a}^{\prime}$ is that it is motivated by fear, leading us to assume that, in this case, the fear is of being subjected to an unpleasant living arrangement with a bad-tempered slave. The next question, for which there is no clear answer, is why the owner does not sell her, instead of faking a manumission that contributes to improving her attitude towards him. Among several hypotheses, the most plausible one leads me to think that there was a feeling of love towards the female slave, to the extent of not wanting to give her away, accepting her rudeness and carrying out a complex legal act. It could be carnal love or simply the affection you have for a babysitter or a former maid. The love felt for someone that you voluntarily decide to tolerate and live with, and in this case with the need to resort to drafting an act before a notary. The use of a secret reservation to settle a marital dispute has been documented, but in this case selling the slave would have been a much easier option. ${ }^{34}$

Surely, she could be completely released, and we will never know why he does not do so. This could be one of those cases in which manumission is considered damaging, those in which the slave is left helpless or neglected; or, simply, that the same love that originated the legal act led its author not to want to be separated from her.

\subsection{This Notarial Model in the Andalusi Forms of Later Centuries}

The continued inclusion of this notarial act in Andalusi manuals from different periods and regions shows that it must have been widely accepted and that its jurisprudence was not disputed. The treatise by Ibn Mughith (d. 459/1067), written in Toledo in the following century, reproduces this notarial model almost word for word. ${ }^{35}$ The publisher did not include it in the edition of the work - instead, it was written on the margins of one of the manuscripts - but later carried out its translation into Spanish in a work dedicated to slavery in

34 Manuela Marín, "Derecho islámico medieval y fronteras de género: Reflexiones sobre textos de al-Burzulī (m. 841/1438)," Clepsydra 9 (2010), 28-29.

35 See his biography in Francisco Javier Aguirre Sádaba, "Ibn Mugīt al-Ṣadafī, Abū Ŷacfar," in Biblioteca de al-Andalus, ed. Jorge Lirola Delgado (Almería: Fundación Ibn Țufayl, 20o6), 4:224-31; also, Ibn Mughīth, al-Muqni', Javier Aguirre's Introduction: 16-25. 
the work of Ibn Mughith. ${ }^{36}$ The record is identical to that of Ibn al-Atțār, but, since the jurisprudence is not included but added in the margin, it does not mention its source, nor can we know the legal analysis done by this notary from Toledo.

This model is also included by the sixth/twelfth-century jurist from Algeciras 'Alī b. Yahyāa al-Jazīīi (d. 585/1189) in his collection of notarial models entitled al-Maqșad al-maḥmud fì talkhịs al-uqūd. ${ }^{37}$ Al-Jazīī places the model among other manumission acts. ${ }^{38}$ The jurisprudence section almost reproduces word for word that of Ibn al-Atțār and directly mentions him as its source.

Therefore, this act was one of the models chosen to pass on from one manual to another. Despite this continuum in theoretical legal works, no evidence has been found on conflicts derived from this specific issue in legal literature, that more directly reflects legal practice, mainly in the form of collections of cases and legal opinions. For example, among the Andalusi jurisprudence from previous centuries included in al-Wansharīisìs extensive fatāwa collection from the ninth/fifteenth century, the author mentions only one reservation document related to a manumission. ${ }^{39}$ It is possible that these reservations were not frequent. Likewise, this is the same for reservation models for pious foundations. Carballeira concludes that the absence of practical cases in this matter is a result of the rare imposition of these conditions. ${ }^{40}$

In contrast with this lack of cases of reservations on manumissions or pious foundations, Müller has excellently documented the use of other types of reservations in al-Andalus. ${ }^{41}$ Undoubtedly, it would be interesting to carry out a detailed analysis of how often other unrelated reservation acts are mentioned - acts unrelated to liberations or pious foundations - in legal

36 Francisco Javier Aguirre Sádaba, “De esclavos a libertos: Fórmulas de manumisión en alAndalus en el s. XI según el Muqni de Ibn Mugīt," Miscelánea de Estudios Árabesy Hebreos (Sección Árabe-Islam) 50 (2001), 48. The text can be found in the margin of the manuscript of Ibn Mugīth's Muqnic preserved in the Real Academia de la Historia, Madrid, f. 99r.

37 Read his biography in Asunción Ferreras, "al-Ŷazīrī, Abū l-Ḥasan," in Biblioteca de alAndalus, ed. Jorge Lirola Delgado (Almería: Fundación Ibn Țufayl, 2009), 7:641-45.

38 al-Jazīīi, al-Maqșad, 432 .

39 al-Wansharīsī, al-Mi'yār al-mu'rib wa-l-jāmi' al-Maghrib 'an fatāwā ahl Ifrīqiyya wa-lAndalus wa-l-Maghrib, ed. M. Ḥajjī (Rabat: Wizārat al-Awqāf wa-l-Shu'ūn al-Islāmiyya, 1981), 9:208.

40 Carballeira Debasa, Legados píos, 334 .

41 Christian Müller, Gerichtspraxis im Stadtstaat Córdoba:Zum Recht der Gesellschaft in einer mālikitisch-islamischen Rechtstradition des 5./11.Jahrhunderts (Leiden: Brill, 1999), 183-88; and Christian Müller, "Administrative tradition and civil jurisdiction of the Cordoban Șạhib al-ahkām," al-Qanțara 21 (1) (2000), 76, 77, 78. 
literature of a practical nature. This type of study would shed light on the issue of the use of notaries to establish conditions on everyday legal procedures. ${ }^{42}$

\section{5 The Sacredness of Manumission and Its Possible Violation}

In these pages, we have seen that Mālikī jurisprudence justifies through complex legal arguments the existence of a notarial model of these characteristics. Nevertheless, this document contradicts the legal spirit of the liberation of slaves, which is aimed at ensuring respect for the Qurannic verses on servitude, where the welfare of slaves and the fulfilment of promises made to them are pursued, as well as granting them freedom, when necessary. At first glance, although we lack in-depth knowledge of Mālikī jurisprudence on slavery, it is evident that this text is full of paradoxes, both legal and human. First, a legal document is drawn up to set a condition on an act - the manumission of a slave - that not only restricts it, but also overturns it. Second, the restraining condition is included not in the manumission model, but in a separate document. Furthermore, it is evident that one of the parties who was part of the manumission, in this case the female slave, was unaware of the existence of the other document. Finally, it is a document intended to overturn what, in principle, cannot be overturned according to the legal school's doctrine itself, because it is an irrevocable act. Although it would not be surprising if actions like these did take place in real life, it is striking that written records are included in a manual that would become a model for contemporary notaries and notaries of future generations.

A quick reading of the legal case of this misbehaving slave, and the reservation placed on her manumission, would lead us to assume that it contradicts the legal doctrine that insists that a manumission cannot be overturned. In fact, there is no such contradiction, because the Mālikī school ensures that there is no retraction in a liberation that has already been carried out, but its jurists allow the slave owner, under some circumstances, to sign a document that allows him or her to foresee the annulment of a manumission that is going to be carried out in the future. The key to understanding this text is the legal distinction between two very different circumstances - one, a deed that has already been considered to be valid before a party then seeks to annul it, which is a matter that is rejected by jurists except in extraordinary circumstances; the other, a legal act that has yet to be carried out, but in which a priori conditions are established. Likewise, the reservation act is a public document, although 
it is carried out behind the back of some of the individuals concerned, and its legal validity depends on the presence of witnesses and the drafting of the notarial certificate. It is, nevertheless, an extreme legal case because the established condition not only restricts but cancels the very object of the contract.

Another relevant reason to give validity to the annulment of the manumission is that it originates in the flawed character of the slave and not due to a noble cause, which somehow eliminates the sacredness of the liberation. Although Ibn al-'Atțār does not explicitly state this in the jurisprudence section, a manumission is a sacred act when it occurs for the reasons mentioned in the Qurān itself. In other words, it is considered as a good deed or as an act of atonement. In our case, the release does not appear to be meritorious for the owner. It is the same as when a pious foundation is instituted without being motivated by a virtuous cause. Ultimately, the legal reasoning in relation to these models implicitly suggests that a religious act - liberation - is valid only when it originates in righteous motivations. A manumission will not be completed if whoever plans to carry it out acts not out of a desire to be a good Muslim, but for human and worldly reasons. The damage that this may cause to the slave is considered irrelevant, since the jurisprudence contemplates only the slave owner's right to fake a liberation by drafting, a priori, a notarial document cancelling the manumission.

\section{Bibliography}

Aguirre Sádaba, Francisco Javier. "De esclavos a libertos: Fórmulas de manumisión en al-Andalus en el s. XI según el Muqni de Ibn Mugịt.." Miscelánea de Estudios Árabes y Hebreos (Sección Árabe-Islam) 50 (2001), 21-51.

Aguirre Sádaba, Francisco Javier. "Ibn Mugịt al-Ṣadafî, Abū Ŷaffar." In Biblioteca de alAndalus, ed. Jorge Lirola Delgado (Almería: Fundación Ibn Ṭufayl, 2006), 4:224-31.

Aguirre Sádaba, Francisco Javier. "Notas acerca de la proyección de los 'kutub al-watāàiq' en el estudio social y económico de al-Andalus." Miscelánea de Estudios Árabes y Hebreos (Sección Árabe-Islam) 49 (2000), 3-30.

Blanc, François-Paul, and Albert Lourde. "Les conditions juridiques de l'accès au statut de concubine-mère en droit musulman malékite." Revue de l'Occident Musulman et de la Méditerranée 36 (1983), 163-75.

Brockopp, Jonathan. "Așbagh b. al-Faraj." In Encyclopaedia of Islam, THREE, ed. Kate Fleet, Gudrun Krämer, Denis Matringe, John Nawas, and Everett Rowson. Consulted online on 16 July 2020 . First published online: 2009 .

Buskens, Léon. "Writers and keepers: Notes on the culture of legal documents in Morocco." In The vellum contract documents in Morocco in the sixteenth to nineteenth centuries, ed. Toru Miura and Sato Kentaro (Tokyo:The Toyo Bunko, 2020), 2:98-125. 
Carballeira Debasa, Ana María. Legados píos y fundaciones familiares en al-Andalus (siglos $I V / X-V I-X I I)$ (Madrid: Consejo Superior de Investigaciones Científicas, 2002).

Chalmeta, Pedro. "Un formulaire notarial hispano-arabe du IV/Xe s.: Glanes économiques." Revista del Instituto Egipcio de Estudios Islámicos 23 (1986), 181-202.

Chalmeta, Pedro. "Ibn al-Ațțār al-Umawī, Abū 'Abd Allāh." In Biblioteca de al-Andalus, ed. Jorge Lirola Delgado and José Miguel Puerta Vílchez (Almería: Fundación Ibn Țufayl, 2009), 2:434-42.

Feria García, Manuel C. Diccionario de términos jurídicos árabe-español (Barcelona: Ariel, 2006).

Fernández Félix, Ana. Cuestiones legales del islam temprano: La Utbiyya y el proceso de formación de la sociedad islámica andalusí (Madrid: Consejo Superior de Investigaciones Científicas, 2003).

Ferreras, Asunción. "al-Ŷazīrī, Abū l-Ḥasan." In Biblioteca de al-Andalus, ed. Jorge Lirola Delgado (Almería: Fundación Ibn Ṭufayl, 2009), 7:641-45.

Gili-Elewy, H. "Soziale Aspekte frühislamischer Sklaverei." Der Islam 77 (1) (200o), 116-68. Gronke, Monika. "La rédaction des actes privés dans le monde musulman médiéval: Théorie et pratique." Studia Islamica 59 (1984), 159-74.

Ibn Abī Zayd al-Qayrawānī, Risāla/La Risāla ou Epître sur les éléments du dogme et de la loi de l'islam selon le rite mâlikite. Texte arabe et traduction française avec un avantpropos, des notes et trois index par León Bercher (Alger: n.p., 1968).

Ibn al-Ațțār, Formulario notarial y judicial Andalusí, ed. Pedro Chalmeta and Marina Marugán (Madrid: Fundación Matritense del Notariado, 2000).

Ibn al-Atțāar. Al-Wathā̉iq wa-l-sïillāt, ed. Pedro Chalmeta and Federico Corriente (Madrid: Instituto Hispano-Árabe de Cultura-Academia Matritense del Notariado, 1983).

Ibn al-Ḥājj al-Gharnāṭì. Al-Wathā̉iq al-mukhtaṣara, ed. Muṣțafā Nājī (Rabat: n.p., 1987). Ibn Mughīth. Al-Muqni` fì 'ilm al-shurūț, ed. Francisco Javier Aguirre Sádaba (Madrid: Consejo Superior de Investigaciones Científicas, 1994).

Ibn Rushd al-Hafĩd (Averroes). Bidāyat al-mujtahid wa-nihāyat al-muqtasid. 2 vols. (Beirut: Dār al-Márifa, 1409/1988).

Ibn Rushd al-Jadd. Kitāb al-bayān wa-l-taḥṣil wa-l-sharḥ wa-l-tawjị̣ wa-l-tálïl fì masāìl al-Mustakhraja, ed. M. Hajjīi, Saīi Árāb et al. 20 vols. 2nd ed. (Beirut: Dār al-Gharb al-Islāmī, 1988-91).

Ibn Rushd al-Jadd. Fahāris al-bayān wa-l-taḥ̂̄ll li-Abì l-Walìd Ibn Rushd, ed. 'Abd al-Fattāḥ M. al-Ḥulw (Beirut: Dār al-Gharb al-Islāmī, 1991).

Ibn Salmūn. Al-Iqd al-munazzam lil-ḥukkām fì-māyajrībayna aydīhim min al-wathāì, edited in the margins of Ibn Farhūn, Tabṣirat al-ḥukkām. 2 vols. (Beirut: Dār alKutub al-'Tlmiyya, n.d.).

al-Jazīrī. al-Maqșad al-maḥmūd fì talkhīs al-'uqūd, ed. Asunción Ferreras (Madrid: Consejo Superior de Investigaciones Científicas, 1998). 
Katz, Marion H. "Concubinage, in Islamic law." In Encyclopaedia of Islam, THREE, ed. Kate Fleet, Gudrun Krämer, Denis Matringe, John Nawas, and Everett Rowson. Consulted online on 14 April 2020 http://dx.doi.org/101163/1573-3912_ei3_COM _25564. First published online: 2014.

Lohlker, Rüdiger. Islamisches Familienrecht. Methodologische Studien zum Recht mālikitischer Schule in Vergangenheit und Gegenwart (Erlangen: Duehrkohp \& Radicke, 2002).

López Ortiz, José. “Formularios notariales de la España musulmana." La Ciudad de Dios 145 (1926), 26o-273.

Mālik b. Anas. Kitāb al-Muwatța' and Al-Ṣuyūṭī, Is āâf al-Muwațta' bi-rijăl al-Muwatța', ed. Farūq Sa'd (Beirut: n.p., 1401/1981).

Marín, Manuela. "Derecho islámico medieval y fronteras de género: Reflexiones sobre textos de al-Burzulī (m. 841/1438)." Clepsydra 9 (2010), 21-40.

Marmon, Sean. "Concubinage, Islamic." In Dictionary of the Middle Ages, ed. Joseph R. Strayer (New York: American Council of Learned Societies, 1982-89), 3:527-29.

Mechri, Farouk. Le sentiment d'affection et le Droit de Famille (Tunis: Editions Latrach, 2015).

Mitter, Ulrike. "Unconditional manumission of slaves in early Islamic law: A hadīth analysis." Der Islam 78 (1) (2001), 35-72.

Müller, Christian. "Administrative tradition and civil jurisdiction of the Cordoban Șāḥib al-aḥkām." al-Qanțara 21 (1) (2000), 57-84.

Müller, Christian. Gerichtspraxis im Stadtstaat Córdoba: Zum Recht der Gesellschaft in einer mälikitisch-islamischen Rechtstradition des 5./11. Jahrhunderts (Leiden: Brill, 1999).

Powers, David S. Law, society and culture in the Maghrib, 1300-1500 (Cambridge: Cambridge University Press, 2002).

de la Puente, Cristina. "The ethnic origins of female slaves in al-Andalus." In Concubines and courtesans: Women and slavery in Islamic history, ed. Matthew Gordon and Kathryn A. Hain (New York: Oxford University Press, 2017), 124-42.

de la Puente, Cristina. "Judicial sources for the study of women: Limitations of the female capacity to act according to Mālikī law." In Writing the feminine, ed. Manuela Marín and Randi Deguilhem (London: I. B. Tauris, 2002), 95-100.

de la Puente, Cristina. "Review of Ibn al-'Atțār, Formulario notarial y judicial Andalusí, ed. Pedro Chalmeta and Marina Marugán (Madrid: Fundación Matritense del Notariado, 200o)." Journal of the Economic and Social History of the Orient 45 (4) (2002), 524-26.

de la Puente, Cristina. "Slaves in al-Andalus through Mālikī wathāiq works (4th6th centuries H./1oth-12th centuries CE): Marriage and slavery as factors of social categorisation." Annales Islamologiques 42 (2008), 187-212. 
Rodríguez Gómez, María Dolores. "Describing the ruin: Writings of Arabic notaries in the last period of al-Andalus." Studia Orientalia 112 (2012), 71-101.

Saḥnūn. Al-Mudawwana al-kubrā. 4 vols. (Cairo, 1323/1905).

Santillana, David. Istituzioni di diritto musulmano malichita con riguardo anche al sistema sciafita. 2 vols. (Rome: Istituto per l'Oriente, 1926).

Schacht, Joseph, An introduction to Islamic law (Oxford: Oxford University Press, 1964).

Shatzmiller, Maya. Her day in court: Women's property rights in fifteenth-century Granada (Cambridge, Mass.: Harvard University Press, 2007).

Tyan, Émile. Le notariat et le régime de la preuve para écrit dans la pratique du droit musulman (Beirut: Imprimerie Saint Paul, 1959).

Wakin, Jeanette. The function of documents in Islamic law: The chapters on sales from Ṭaḥāwìs Kitāb al-shurūṭ al-kabīr (Albany: State University New York Press, 1972).

al-Wansharīsī. Al-Mi'yār al-mu'rib wa-l-jāmi' al-Maghrib 'an fatāwā ahl Ifrīqiyya wa-lAndalus wa-l-Maghrib, vol. 9., ed. M. Hajjì (Rabat: Wizārat al-Awqāf wa-l-Shu'ūn al-Islāmiyya, 1981).

Zomeño, Amalia. "From private collections to archives. How Christians kept legal Arabic documents in Granada." al-Qanțara 32 (2) (2011), 461-79.

Zomeño, Amalia. "Notaries and their formulas: The legacies from the University of Granada." In From al-Andalus to Khurasan: Documents from the medieval Muslim world, ed. Petra Sijpesteijn, Lennart Sundelin, Sofia Torallas Tovar and Amalia Zomeño (Leiden: Brill, 2007), 58-77. 